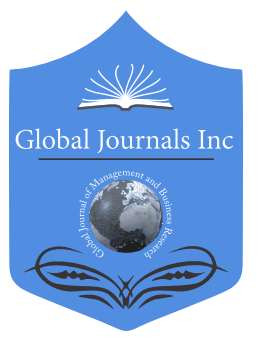

Global JOURnal of MANAGEMENT AND Business ReSEARCH: A ADMINISTRATION AND MANAGEMENT

Volume 21 Issue 5 Version 1.0 Year 2021

Type: Double Blind Peer Reviewed International Research Journal

Publisher: Global Journals

Online ISSN: 2249-4588 \& Print ISSN: 0975-5853

\title{
Management Research: Discussion on Leadership Study Area
}

\author{
By Tewogbade Shakir
}

Abstract- The study is to review leadership problems in management research. The discussion addresses the problems from theoretical backgrounds and reveal the possible leadership styles and behaviours seen in business world when such problems are experienced. Possible ways of managing the problems in order to minimize the negative effects on business outcomes was also discussed. This discussion will set pace for further specifics research in any organization settings having identified possible problems and how to formulate research questions.

GJMBR-A Classification: JEL Code: M10

Strictly as per the compliance and regulations of:

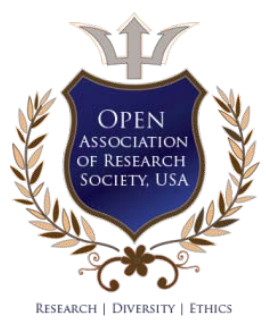

(C) 2021. Tewogbade Shakir. This is a research/review paper, distributed under the terms of the Creative Commons AttributionNoncommercial 3.0 Unported License http://creativecommons.org/licenses/by-nc/3.0/), permitting all non-commercial use, distribution, and reproduction in any medium, provided the original work is properly cited. 


\title{
Management Research: Discussion on Leadership Study Area
}

\author{
Tewogbade Shakir
}

\begin{abstract}
The study is to review leadership problems in management research. The discussion addresses the problems from theoretical backgrounds and reveal the possible leadership styles and behaviours seen in business world when such problems are experienced. Possible ways of managing the problems in order to minimize the negative effects on business outcomes was also discussed. This discussion will set pace for further specifics research in any organization settings having identified possible problems and how to formulate research questions.
\end{abstract}

\section{INTRODUCTION}

$\mathrm{R}$ esearch is the process of searching for knowledge either to establish fact about existing phenomena or bringing out new phenomena in their entirety. When such a search is carried out in the business world to study and investigate organizational issues, we have Management Research. Management research is the process of planning, acquiring, analysing and disseminating relevance data, information and insight to decision makers in ways that mobiles the organization to take appropriate action that, in turn, maximize business performance (Copper and Schindler 2007). Management research engages both the world of theory and the world of practice (Umesh and Nitin 2014) and utilizes both epistemology and ontological philosophies. Management research is readily applied to proffer solutions to various problems that exist in an organization through decisions that are justifiable by relevant data and information. Such research can easily be carried out when one combines theoretical and dayby-day practice exposure to identify problems faced by the organization and how they can be addressed. One of such problems in the business/management world that was discovered to exist in many organizations is leadership problem which was discussed considering its possible effects on organization performance.

Leadership as one of the core area of management research was conceptualized by discussing its various theories, functions and future expectations. This study shows how research statements can be formulated for leadership problems that exist in an organization across specifics issues such as ineffective communication, non-clear direction, slow

Author: B.Sc. Physics, MBA, DBA student (UCAM). Shakir has over 13 years' experience working in Financial Institution and two of his previous articles have been published by America Society for Quality (ASQ) in 2014. Currently, a Relationship Manager with First Bank of Nigeria, Ltd. e-mail: pingcommercial@gmail.com pace in adopting supportive technologies and poor human resources handling which affect the business outcomes. Similarly, data collection methods were highlighted while the suitable means for this type of investigation were identified with matching data analysis procedure. Consideration was given to ethical issues that could arise in this type of research and discussion on how the research can be fashioned to avoid them was made.

\section{Conceptualize Management Research}

Research has been referred to as an act of searching for a fact about what exists or bringing new existence (innovation). It is defined by scientific and systematic search for pertinent information on a specific topic/area (Syed M, 2016). It is normal to search or make enquiries into different phenomena while it is very important to ratify such systematic inquiries in order to discover new knowledge or consolidate existing one. One of the aspects of society where research is carried out is management in business world. Management research involves searching for facts that will assist management in making effective business decisions. Tharenou et al. 2007, confirmed that management research exists in the general management field and related disciplines. The overall theme is to apply research techniques to real-life management issues and problems. It specifically put forward theoretical and practical issues in the business world which are hardly experienced in other aspect of nature-physical or social sciences. This reflects the main feature of management research where it merges both theory and management practice. The whole process involves setting an investigative plan, acquiring necessary data, analyzing the data and producing outcomes that support decisions to be taken. The whole process is to understand various social, economic, psychological phenomena that exist in an organization and how they affect outcomes and performances.

Contemporary management research has precedent from management theories that revealed the form of such researches. The two earliest approaches are:

\footnotetext{
i. Epistemological school

ii. Ontological school
} 
Epistemological School: Epistemology is coined from Greek, where Episteme stands for knowledge and logos stands for reason. The epistemological approach organizes and explains knowledge in the form of theories (Geoff, 2005). Epistemology schools provide the foundation for "warranted knowledge" in business world. It studies criteria by which we can know what does and does not constitute warranted knowledge (Johnson \& Duberley, 2003). It is superiorly concerned about what type of knowledge do we produce through research, how they are accumulated and presented. It shows a systematic approach on researcher's knowledge of reality and the underlying meaning of it.

Epistemology will study the connecting link between the individual carrying out research and reality and how is the reality discovered. Who is doing research and where/when the research is conducted (Prabash, 2012). Epistemology does not only study knowledge, it goes further to study how the knowledge is acquired and presented. Most importantly, it set the limit between the kinds of knowledge that are vital and sufficient.

Ontological School: ontology is concern with nature of being. In contrast, epistemology is about "what it means to know" while ontology is "what is". Ontology deals with what actually in existence which humans can derive knowledge, the nature of reality and what really exists. Ontological philosophical approach establish claim on what is real and its legitimacy. The ontological school has two important views, which are: positivism and subjectivism.

Positivism which also known as objectivism is the stance which postulates nature and their meaning have an independent relationship with the social actors. By extension, such existence is independent of the mind or any other cognition. What is real is unique and general regardless of the belief or perspective of the researcher. Thus, a management researcher can select a segmented means in carrying out an investigation by establishing a valid and clear topic, formulating unbiased research questions and applying resultoriented research procedures.

Subjectivism school takes a stance on mutual interrelationship and dependency between researcher and nature under study. The researcher has prior knowledge about nature, which is believed to be insufficient. Unlike objectivism philosophies, no uniqueness as there exist many perspectives to which management researchers will be exposed to.

Management research is a process of establishing truth or state of fact about business issues or phenomena. The propelling force for such study is the ability to formulate knowledge and advancement. Don-Solomon et al. (2018) posit that successful research through knowledge building is strongly supported by epistemology and ontology philosophies. The two schools formed the background philosophies utilize in management research where researchers can either adopt independent interactions in the business environment or stance that there exist a relationship between the researchers and the phenomena to be investigated.

\section{Knowledge Area in Leadership}

Management research which is the process of utilizing information that has been gathered and analyzed to proffer solutions to known organization issues or problems, includes subject area such as Human Resources, Marketing, and Leadership. The overall focus of any organization is the bottom line which is the outcomes of all transactional/business/operational activities. Leadership as a study area in management research show links about input values and organization outcomes. Smith et al. 1984 viewed leadership as lead factor in producing this outcome and organizational performance. The purpose and function of leadership in delivering superior organizational performance cannot be over-emphasized. Leadership drives desirable working environment, optimal workers' motivation, fair compensation and productive communication to yield excellent performance. The leadership style, act, behaviour and value being delivered all have an impact on organization indices and outcomes. In short hand, we can consider leadership as attitudes/behaviour of business leaders in directing subordinates towards organizational goals. Leadership appears in different forms: communication process, business activities, influencing process, source of inspiration. In totality, it is a combination of organizational processes, overall system and all forms of relationships influenced by the leaders.

Leadership, which is one of the management subject areas in an organization setting, is as old as the history of people. It is a subject area connected to different disciplines such as organizational studies, management studies, political science, sociology, psychology and education. Leadership has been defined in many ways by different authors and researchers. Few among them are:

1. Leadership is the ability of a manager to induce subordinate to work with confidence and zealKoontz and O'Donnell.

2. Leaders is the activity of influencing people to survive willingly for group objectives-George R. Terry.

3. Leadership is the exercise of authority and making decisions-Dubin $\mathrm{R}$.

Over the years, different leadership theories and approaches have been formulated to solve issues that exist in organizations under certain situations. The main contributions to the early era of leadership studies were classical and scientific management theories 
(Muhammad \& Sadia, 2018). The first theory of leadership developed in 1990 is The Great Man Theory. The theory stipulated that leadership is an innate ability. The theory solidly view leader as being born and not made. The basis is to study what traits are exhibited by performing leaders and non-performing leaders. David Kolzow, 2014, identified such personality traits linked to effective leaders in his book:

i. Intelligence -

ii. Creativity - innovate

iii. Self-confidence - Trust in themselves

iv. Drive

v. Credibility - honesty all time

vi. Motivation - motivate followers to meet set targets

vii. Flexibility - adapt to fit current needs

Even though many other researchers have revealed many other traits. Traits such as selfconfidence, alertness, intelligence, sociability, among others, were identified by Stogdil in 1949 and 1974. Mann (1959) came with over five hundred measures of personality traits related to effective leadership.

After the great man and trait theory, behaviour theory came into existence (1950 - 60). Behavioural theory masked the behavioural patterns result in leadership. While trait theory focuses on leaders' personality, behavioural theory focuses on behaviours of leaders. Evidently, from behavioural theories, leadership styles can be learned by masking the behaviours shown by a leader. The behavioural theories include two types of behaviours: task behaviours and relationship behaviours (Northouse, 2007). While it can be difficult to measure traits, researchers switch to measuring leadership behaviours. Since behaviour embodied the traits. As noted by David K (2014), it is more valid to measure behaviour than personality traits because behaviour shows actions that can be observed. Behavioural theory stipulated that leadership can be learned for an individual to become an effective leader. Allen 1998, posits that through training, leadership styles and behaviour can be learned. Various contributions have been made through various studies such as Ohio State University research (by Stogdill, Loons, Halpin, Winer and Fleishman) and University of Michigan studies (Katz and Klahn). The concept of "concern for task" (product-oriented) and "concern for people" (employee-oriented) behaviours were identified as common leadership behaviours (Gill, 2006) where this model of leadership behaviours was termed Managerial Grid (Blake \& Mouton, 1994). The Blake and Mouton Managerial Grid, also known as the leadership grid, show five classes of leadership behaviours.

\begin{tabular}{|c|c|c|c|c|}
\hline \multirow{4}{*}{$\begin{array}{c}\text { Concern for } \\
\text { People }\end{array}$} & High & Country Club Style & & Team Style \\
\cline { 2 - 5 } & & & $\begin{array}{c}\text { Middle-of-the } \\
\text { Road Style }\end{array}$ & \\
\cline { 2 - 5 } & Low & Impoverished Style & & Productive Style \\
\hline & & Low & & High \\
\hline
\end{tabular}

a) Blake and Mouton Grid-The Managerial Grid: Gulf publication, Houston, US, 1994

The product-oriented behaviour involves technical means of task accomplishment while employee-orientation is basically on how followers should be taken as human being such that their individuality is valued and their needs are attended to. Other researchers have also classified leadership styles:

Likert: Consultative, Exploitative Autocratic, Democratic and Benevolent Autocratic

Tannenbaum and Schmidt: autocratic, persuasive, consultative and democratic

From Blake and Mouton grid:

a. Country Club Style (High People: Low Task): there is more focus on people with minimal effort for the task. There is superior energy in making people happy and creating a very pleasing and comfortable environment. This style is defective as there is low concern for the task that produces outcomes.

b. Impoverished Style (Low People: Low Task): the worst class of leadership in Blake and Mouton table.
The leaders care less about the followers and poor concern for the task that will yield results.

c. Middle of the road style (Mid People: Mid Task): there is some compromise between concern for people and concern for the tasks. It could be ineffective when compromise shows a loss of authority and decisiveness.

d. Produce/Perish (Low people: High Task): this class shows deep concern for the task with minimal focus on people. It is also known as the autocratic style of leadership. It is often utilized to take total control of employee and it might not be sustainable in the long run if the employee has a better option.

e. Team Style (High People: High task): This is the ideal class of leadership behaviour where there is a high level of focus for both the task and the people; as a team, everybody is involved and the strong collaboration to deliver tasks. 
After behavioural theory, contingency /situational theory was proposed around 1960 - 70 to study which leadership behaviours are better under certain situations. What produces effective outcomes for a particular leader in certain situation might not work in another situation. Some situations are captured under contingency theory or situational leadership theory. To fully understand the effectiveness and performance of leaders, it is necessary to understand the situation in which they lead (Muhammad \&Sadia, 2018). The theory explores two variables (leadership style and situational variables) and the relationship between them. Howell, Dortman and Kerr, (1986) identified the following situational variables:

i. Relationship quality between leader and subordinates

20 ii. Structure of task

iii. Availability of information

iv. Maturity level of the subordinate

v. Unclear tasks or roles of the subordinates

vi. Degree to which subordinates are willing to accept the decisions of the leader

Hershey and Blanchard 1982 suggested four primary leadership styles:
i. Telling
ii. Selling
iii. Participating
iv. Delegating

Which were further reclassified based on maturity level:
i. Low Maturity (M1) - Telling (S1)
ii. Medium Maturity (M2) - Selling (S2)
iii. Medium Maturity (M3) - Participating (S3)
iv. High Maturity (M4) - Delegating (Sarachek, 1968) (S4)

In advancement of situation postulation, Fred Fiedler (1967) discussed the effectiveness of leadership styles as dependent on the suitability of the situation through his least preferred co-worker analysis. His proposition is based on three parameters:

\section{i. Task structure \\ ii. Position of power held by a leader \\ iii. Relationship between leader and members}

The path-goal theory developed by House (1971) added motivation of employees as a choice in leadership styles. Leaders can influence their followers to comprehend the task ahead and how to achieve set goals. Beyond motivation, the level of relationship between leader and follower will show significant inclination on organization performance. Krishnan (2004), when the quality of exchange between leader and follower increases, progress also begins to increase. Leader-member exchange (LMX) theory shows superior outcomes in accordance with the relationship between leader and follower through psychodynamic exchange between them. According to Graen \& Uhl-Bien and mentioned by Gary Yulch, higher quality of exchanges between supervisors and subordinates results in
1. Less turnover
2. More positive performance evaluations
3. Higher frequency of promotions
4. Greater organizational commitment
5. More desirable work assignments
6. Better job attitudes
7. More attention \& support from the leader
8. Greater participation

From the situational and exchange era of leadership theory, the study shifted to the transactional era, where leadership is viewed based on role and social interaction. The first person to use the terms transformational and transactional is Downton, in 1973. In 1978, Burns classified leadership styles based on followers' motivation; he considered transformational leadership to be way of motivating followers by concentrating on their values to show effective outcomes. He considered the transactional leadership as a way of social exchange to effective employee performance towards targeted goals. Followers are controlled through the consequences approach (reward/penalties). Transformational leadership is defined as leader behaviour that inspires and motivates people to perform beyond expectation (Bass, 1985) and is particularly affiliated with organizational commitment (Bass and Riggio, 2006). The higher driving force of influence by transformational leaders will ignite the followers toward superior performance. Burns 1978, postulated that transactional leaders concentrate on followers' self-interest, where they are motivated by exchanging different items such as salary, bonus.

Transactional leadership consists of leaders guiding and motivating followers by appealing to the follower's own personal interests (Bass, 1985). They give clarity to performance standards and articulate expectations of desired outcomes (Chiau et al., 2011). Even though transformational and transactional leaders influence employees in task accomplishments with supportive relationships and communication (Bass, 1990a), the transactional leader is more likely to compromise some form of need satisfaction for values such as salary increase, improvement or recognition (Neilsen \& Munir, 2009). The transactional leadership style encourages standard forms of incentives, reprisals and sanctions to control employees (Bass \& Roggio, 2008). Calloway and Awadzi (2008) agreed that transformational leaders operate at a higher degree of motivation (communicating with employees, opportunities to grow, self-motivation, training). 


\begin{tabular}{|c|c|}
\hline Transformational Leadership & Transactional Leadership \\
\hline It is proactive & It is responsive \\
\hline $\begin{array}{l}\text { Work to change organizational culture by motivating new } \\
\text { ideas }\end{array}$ & Works within organizational culture \\
\hline $\begin{array}{l}\text { Motivate employee to achieve companies' objectives by } \\
\text { appealing to higher ideas and moral values }\end{array}$ & $\begin{array}{c}\text { Make employees achieve organizational objectives } \\
\text { through rewards and punishment }\end{array}$ \\
\hline $\begin{array}{l}\text { Motivate followers by encouraging them to translate their } \\
\text { own interests for those of the group or unit }\end{array}$ & Motivates followers by appealing to their own self-interest \\
\hline
\end{tabular}

Table copied from Prachi Junega, 2019. Transactional leadership theory.

https//managementstudyguide.com/transactional-leadership.htm

\section{b) Full Range Leadership Model}

Past researchers include theories that often concentrate on single leadership styles and behaviours whereas leaders do show more than one style and behaviours. Hence the need to extend the study to various styles and behaviours exhibited by leaders. The study of how leaders make use of multiple behaviours and style is captured in full range leadership theory. The full range leadership theory is unique in that it combines elements of transactional, transformational and laissezfaire leadership into single model (Sadeghi and Pihie, 2012). The theory is recent and interest in it, is due to the combination of other leadership theories (transactional, transformational and laisse-fairez). The need to develop FRL theory is easily noted due to existence of gaps and overlaps in previous theories. In $\mathrm{FRL}$ model, nine variables are represented by three leadership styles.

Transformational leadership style: inspire \& motivate followers through

i. Compelling vision

ii. Individual support

iii. Empowerment

Five behaviours:

i. Idealized influence (attributed)

ii. Idealized influence (behavioural)

iii. Inspirational motivation

iv. Intellectual stimulation

v. Individual, consideration (Mazurkiewics

Ravazadeh \& Ravazadeh, 2013)

2012

Transactional leadership style: three behaviours

i. Contingent reward

ii. Management-by-exception (active)

iii. Management-by-exception(passive) (Meyer 2013, Robinson and Boies, 2016, Northouse, 2013)

Briefly, laissez-fares propounded in lowa Studies by Lewin, Lippitt and White which shows no involvement with followers (Sudha and Farhat, 2016)

c) Adaptive Leadership Theory

The advancement in technology, progression in organization operations, large needs of business entity with other leadership demand has suggested continued study to expand FRL. There is a need for a leader to be able to adapt to varieties of situations and events in his/her immediate environment by utilizing varieties of behaviours and attributes noted in previous theories.

d) Organizational Leadership, Implications and Future of Leadership

The theories reviewed from "Great Man" to adaptive leadership theory have all indicated a relationship between leadership styles/behaviours and the followers (employee) in the face of the organizational outcomes/outputs.

As noted by Allio (2013), each of the theories, right from the great man theory to the most adaptive theory has revealed standard skills, styles and behaviours needed by leaders to lead effectively. As there is progression in the business world, there are also various leadership issues emanating from one generation to another. Millennials adapt easily to advancements in technology, unlike older generations. The newest generation (GenZ) or iGen is the first generations after the invention of the internet. Thus, they grow up digitally connected to the whole world around them. It is easy to feel leadership with inclusivity and curiosity.

In a similar vein, technological advancement has created the e-leadership phenomenon. The rapid and continuous changes in technology have modified communication and other aspect of organization processes which created a new requirement for leaders to adapt to e-leadership means. Recent global happenings, COVID 19, have made various organizational practices to become virtual. This means of communication and collaboration has become the new normal and there is room for study on how it affects leadership. Future leaders will be facing challenges linked to technological discoveries as they support day to day activities of organization settings such as virtual teaming, globalization and e-leadership.

E-leadership, and the virtual team setup are moderated by electronic means where collaboration, communication and other processes are carried out over spatial distances with the help of ICT gadgets. Few critical questions on the success of e-leadership for the future are:

i. Effect of technology on quality and quantity of the communication. 
ii. Trust issue \& trust formation on leadership across technology.

iii. Effect of the structure on leadership style as it. affects performance and innovation of the followers.

\section{Leadership Organizational Problem}

Leadership practice is becoming increasingly important in the modern organization, where change is an inseparable part of the organization (Muhammad 2016). One of the major problems in any organization is leadership issues. This assertion can be supported by asking selected staffs of the organization independently if they consider leadership as one of the major problems facing their organization. Overall leadership problem in any organization is considered suitable for management research because investigation and study can be easily carried out along specifics issues such as
i. Communication
ii. Clear and coherent direction
iii. Slow network adoption compares to competitors
iv. Human resources management

1. Ineffective Communication System

First and foremost, why leadership is considered as a problem is due to incoherent and inconsistent communication. Communication is an essential phenomenon for effective leadership. Every organization has a strategic goal and targeted objectives to achieve, these objectives/goals must be well communicated to the followers in such a way that drive and motivate them (as discussed in transformational theory), so they can perform excellently. Effective leaders communicate effectively to avoid bottlenecks along strategic, structural, procedural divides in an organization and ensure channels remain open (up and down or horizontal-participative, democratic styles). As organizations develops strategic changes to tap into wider opportunities and deliver excellent performance, there is a need for effective communication to influence the followers to adapt to the changes. Another aspect of leadership communication issue is Trust. Trust is the factor that followers consider to get assurance that their leader will be truthful and display ethical behaviour in all situations. For perfect trust level, effective communication is a key factor. Communication plays an important part in trust-building by stimulating a fair environment where leaders are empowered to effectively lead and motivate their followers. Trust is built when leaders communicate essential information needed to motivate and improve performance. Lastly, on communication issues, Benith Zulch in 2014 noted the relationship between leadership style and communication process. Leadership styles have proved to be one of the key components of an effective organization (Munevver et al., 2012). Communication approaches adopted by a leader can be traced to his/her natural inclination some specific leadership styles. An open leadership style will influence creativity, innovation as there will be a free flow of ideas and shared information which will improve effective communication. Participative and democratic leadership styles promote open discussions that deliver effective communication. Similarly, the transformational leadership style creates collaborative and decentralized communication that improves performance. Charismatic leadership aids communication which only promotes a leader's information and decisions, while autocratic leaders are one-way means of communicating leaders' instructions. All these aspects -effective communication, trust built from communication and communication based on leadership styles- observed in my organization provides a wider room for empirical investigations, which is suitable for management research.

\section{Clear and Coherent Direction}

Leadership is the process of direction, guidance and influencing others and establishment of interpersonal relationships for the achievement of the objectives of the organization yielding satisfaction to all (Kavinakar and Datta, 2015). It is total means of influencing followers and harnessing their combined efforts towards identified goals. For superior organizational performance, the whole processes and systems must be aligned to stimulate a coherent and strong sense of direction. As written by Kurt et al., 2019, in as much as it is important to have ambitions that create a better future, it is also compulsory to translate plans, drives and momentum into a well-defined direction. A clear and coherent direction improves the effort to handle organizational changes needed to meet targeted goals. In the recent years, there have been many overlapping projects which display inconsistency in handling some strategic drive (structure and processwise). It is a big drawback when two almost similar software applications are deployed instead of a more robust system that can deliver competitive solutions. Many times, resources and manpower time are wasted in driving half-baked changes. The impact of driving clear direction and vision cannot be less emphasized as resultant effect on proper alignment of resources (financial, human, material) at proper timing will lead to a sustainable performance. Colfax et al. 2009 empirically confirmed that some proper alignment will improve productivity up to $70 \%$.

\section{Slow Technology/Digitization Adoption}

There are different approaches to studying leadership (Jeroen et al., 2005), and technological adoption based on leadership personality is one of the approaches. As studied by Jeroen et al in their study of TAM (Technology Acceptance Model), transactional leadership style will prefer the introduction of technologies in order to reduce cost. In a close related 
manner, transformational leadership style will influence employee to be more inquisitive, creative and ready to utilize technology due to its core usefulness. As transformational leaders drive creativity and innovation, employees will be eager to accept new technologies. This is a great pass, for such leader to adopt more advance technological changes for the organization and remaining competitive.

4. Human Resources Management - blending multiple personalities into a unified team

Human resources management is very essential to any organization. Few human resources issues affected by poor leadership as seen in some organizations are

i. High labour turnover

ii. Low morale

iii. Subjective performance measurement

iv. Pressure to deliver target and budget KPI in the face of harsh economy / natural occurrences (COVID 19)

v. Ineffective bonus/performance pay system

Good leadership will leave a person feeling supported, stable and motivated (Kellerman, 2004). Low employee morale and poor motivation will affect organization negatively. In his study, Chionk 2001, produced positive correlation between leadership styles, job satisfaction and employee commitment. Transformational leadership gives room for freedom and wider responsibilities for employees which stimulates accomplishments and job satisfaction. Performance appraisal must not be subjective in order to avoid low staffs morale. Tuytens and Devos (2012), when appraisal is done objectively, it will show significant effect on staffs' motivation. When it is done without agreed objectives and clear goals, it leads to dissatisfaction which will result in poor productivity. The end of year appraisal should be tailored to the specific job and realistic KPI are set in order to increase perceived fairness and appraisal system that is well accepted by everyone. Enterprise-wide feedback should be encouraged in appraisal and performance measuring cycle. Oberg (1972) stated that feedback has important role in various practices carried out in an organization as it shows fairness and rationality. Management should ensure clarity, openness and fairness and staff should have confidence that the appraisal system is fair. Most importantly, the system should be reviewed on regular basis while taking feedback into consideration.

\section{Research Question to Address LeAdership Problem}

Leadership in all spheres must necessarily be effective in order to achieve personal, group and /or organizational success (Rafique, 2014). Leadership styles have great impact on all organizational resources and the whole system.
The core objective of this study is to investigate leadership problems which can be tailored towards leadership styles and organizational outcomes. Thus, the basic primary research question is: how do leadership styles affect organizational performance? The primary research question is approach by the following sub-research objectives:

a. Study leadership styles observed on communication drives in the organization

b. Study the impact of leadership styles observed in the organization on goal setting, vision drives and clear direction strategy as they affect overall performances

c. Study impact of leadership styles observed in the organization as they affect human resources based on performance appraisal measurement, labour turnover, morale level, job satisfaction and motivation

d. Study and investigate leadership styles in cognizance with technology/digital adoption level in comparison to competitors

\section{Stages in Research}

The following stages will be considered in investigating the research question and sub-questions:

1. Exploratory stage

2. Research questions and hypotheses

3. Data collection

4. Data analysis

\section{a) Exploratory Stage}

Research is basically act of producing solutions to phenomenon issues at hand after carrying out analysis of all factors leading to the situation. Considering this research in leadership, we start by reviewing varieties of literatures on leadership and organizational performance broadly. This will help to spot the connecting links between leadership and organizational outcomes which will be used to drill down the research questions. Real cases on leadership will be explored across the world not limiting to Nigeria alone, on how leadership impact on organizational results. Also, selected discussion should be carried out among few staffs (independently) in the organization under study.

\section{b) Research Questions and Hypotheses}

Formulating research question(s) is an essential part before starting the research itself. This allows us to explore occurring uncertainty in leadership styles as it affects performances. Kishore et al, (2011) mentioned that a good research question forms backbone of a good research which in turn is vital in unravelling mysteries of nature and giving insight into a problem. Our research question will identify leadership problems to be studied while providing overall focus to the 
research methodology. Most importantly, it will lead us to hypotheses needed in our research. A standard and well drafted research question summarizes the problem statement, gives description of the issues being study, directs data collection approaches and reveal how data analysis should be carried out.

After formulating research question, we developed research hypotheses where we make prediction about aspect of leadership styles impacting on enterprise performance. Standardly, a null hypothesis is produced which will be accepted or rejected after research investigation. Hypothesis is a proposition that links situational variables which we can run empirical test on. Being testable is an important feature of a good hypothesis as supported by Kerlinger \& Lee 2000.

\section{c) Data Collection}

Data collection is the standard procedures of taking fact and records of items observed during research study. Though overall process of collecting data is the same for different types of studies, the methods might be differ. There are four steps necessary in order to collect data of high-quality.
a. Defining the purpose of the study
b. Select data collection method
c. Plan procedures for the collecting the data
d. Collect data

Defining the Aim of the Research: Formulated research questions will determine type of data to be collected (qualitative or quantitative). Quantitative data are in numbers and statistics. They give countable outcomes where we can easily compute averages, highs and lows. Qualitative data are in words and they are further sorted out through some classification and categorizations. Since investigation at involves many aspects of leadership problems, we will be using mixed methods to collect both types of data. As discussed by Antanok is et al 2004, both qualitative methods and quantitative methods will be used due to complexity in leadership phenomena. Qualitative methods will reveal the exploratory aspect while quantitative show description and explanation.

Select Data Collection Method: Based on the data we are collecting in step (1) above, we will select most appropriate method for our leadership research.

\begin{tabular}{|c|c|c|}
\hline Method & When to Use & How to Collect Data \\
\hline Experiment & To test a causal relationship & $\begin{array}{c}\text { Manipulative variables. Measure their } \\
\text { effects on others }\end{array}$ \\
\hline Survey & $\begin{array}{c}\text { To understand the general } \\
\text { characteristics or opinions of a group } \\
\text { of people }\end{array}$ & $\begin{array}{c}\text { Distribute a list of questions to a } \\
\text { sample online, in person or over the } \\
\text { phone }\end{array}$ \\
\hline Interview/Focus group & $\begin{array}{c}\text { To gain an in-depth understanding of } \\
\text { perceptions or opinion on a topic } \\
\text { Observation }\end{array}$ & $\begin{array}{c}\text { Verbally ask participants open-ended } \\
\text { questions in individual interview or } \\
\text { focus group discussions }\end{array}$ \\
\hline Secondary data & To understand something in its \\
that you cannot access at first hand & $\begin{array}{c}\text { Measure or survey a sample without } \\
\text { trying to affect them }\end{array}$ \\
\hline already been collected from sources \\
such as government agencies or \\
research organizations
\end{tabular}

Extracted from Pritha Bhandari, (2020). A step by step guide to data collection.

https://www.scribbr.com/methodology/data-collection/

Survey method will be selected for our leadership study as it is scientifically cheap and easy to carry out. Survey methods have been used to answer many types of research questions emanating from all leadership perspective (Antonakis et al., 2004).

\section{d) Survey - Study Poupulation, Validity and Reliability}

Population is total number of selected items identified to be studied. Since there will be a constraint in study everyone in the process of data collection, a sample size is often selected and the result is generalized for the total population. Sample size is selected based on subset of population majorly affected by the research. In most research work, it is easier to study chosen part of the total part (sample) to save time and other resources while the outcomes are generalized for the total population.
Validity is concerned with an evaluative judgment about an assessment (Gregory, 2000) and the values range from low to high. It shows how well the method selected will reveal accurate reality. For a valid research, what we measured will be considered accurate. Reliability display consistency in deriving same result on different but comparable situations. Such research can be replicated and we still get similar results. In order to get a valid and reliable research, survey questionnaire will be completed by staff (leaders/employee) of First Bank while a pre-test check will be carried out by supervisors/functional managers. As stated by Kerlinger, there should be strong between research problems, the way the study is designed, data to be collected, the way the data will be analyzed and inferences made from the outcomes. 


\section{e) Data Analysis}

There are various statistical packages (SPSS, R, Matlab, Microsoft Excel, SAB, and Minitab) that can be used to analyse the data collected and eventually test research questions and hypotheses. Data analysis will include:

i. Description Statistics- mean, standard deviation for leadership styles and organizational performances

ii. Multiple Regression - to study connection between situational variables (dependent and independent variables)

\section{Vil. Ethical Issues in Research}

Ethics involves moral guidelines which direct individual behaviour. The set of principles direct how individuals interact with themselves base on what is right or wrong. Also, ethics provides moral solution to such situations where action to be taken is unclear. Since research in leadership involves data collection from people then moral principles is needed in protecting all stakeholders in the course of the research. . Ethical issues exist at all stages of research and they will be discussed one after the other.

i. Ethical Issues at Research problem stage: identification of research problem is an important stage which laid foundation for the research and thus the problem identified should be meaningful to all stakeholders (participants and respondents) to avoid waste of resources (time, material, financials). It is unethical to take opinion from various participants when there no meaningful research problems or non-beneficial issues. Similarly, as supported by Agwor \& Osho (2017), it will be deceitful to have other reasons different from the one gave to participants. Similarly, there are three main ethical issues at this stage:
a. Waste of resources (research not important)
b. Misleading or fraudulent
c. Unnecessary research for financial/personal gain (Ruhi and Nolan, 2014)
d. Ethical Issues when reviewing literature: Ruhi \& Nolan identified four likely issues at this stage
e. Biased search and view
f. Conflicting evidence ignored
g. Quoting out of context
h. Plagiarism

There is need for superior consideration for ethical values of review of literature in order to avoid act of copying other people work knowingly or unknowingly. Also noted by Agwor \& Osho, ethical issues at this stage also involve "genetic copying" (duplicating another person's work without referencing), cut and paste (text from a portion without editing), act of changing keywords/phrases while major content from the source is retained, act of paraphrasing from different sources and act of recycle one work in different publications.

ii. Ethical Issues at data collection stage: at data collection we have issues such as:

a. Manufacturing data to yield target result. Widely observe in quantitative research methods

b. Data recycle usually observe in qualitative research methods

c. Consideration for confidentiality and anonymity such that participants are not put to risk

d. Act of bribing to get data

iii. Ethical Issues at Data analysis stage: where data collected are presented, analyzed and discussed (Agwor and Osho, 2017) and it is of high standard to make use of unbiased instruments and approaches that yield ethical results. Issues listed below are seen at this stage

a. Act of ignoring contradictory data during data analysis

b. Manipulating data to produce targeted results

c. Precise and statistically justified interpretation should be provided

iv. Ethical Issues at conclusion/recommendation stage: The act of intentionally making false or biased conclusions and recommendation is a major ethical issue at this stage

a) How Will This Research Be Designed To Avoid Ethical Issues

Considering the research designed stages from research problem stages to research conclusion/recommendation. The following steps will be utilized:

1. Research selection: a simple survey will be held with selected colleagues across functional divide in order to justify the research question selected. There should be a common opinion that the problem to be selected is meaningful and beneficial to all stakeholders in this research. Full disclosure of what the research will entail will be revealed while seeking common opinion from other colleagues. This will remove act of deception of research purpose. With this, bias opinion by the researcher alone can be avoided as there is agreed/well established justification for the study

2. All of form of plagiarism is avoided when reviewing literature by keeping track of all sources of past work and full acknowledgement is given. Paraphrasing and text-recycling will be avoided by reading to understand the previous work and ensuring reference of the source are done properly. Respect for intellectual property will be highly observed during the course of research 
3. Data will be collected in non-harmful procedures and with necessary consent to do so while confidentiality and anonymity is guaranteed. Adequate permission will be taken from Management of the Bank if there is need for institutional records. All information obtained about the participants or the Bank itself will be kept in confidence. Accurate and truthful will be collected by engaging the right participants (staff of the Bank) while ensuring functional supervisors/managers verify information supplied before analysis is carried out. This will erase issue of data falsification and fabrication. Face to face interviews are held where there is any of form of unclear information. Data collected will be secured/stored safely to preserve integrity and privacy of the data.

4. Data will be analyzed in such manner that portrays truthful utilization of data collected. All analysis will be done beyond personal emotions, motives and obligations. All data analysis and results will be interpreted carefully to avoid error due to negligence and making sure that the results are reliable.

\section{Vili. Conclusion}

Management research is the systematic processing of information utilized in making effective decisions in various organizations. The scope of management research includes HRM, marketing management, production management, financial management and leadership handling. For an organization to perform well there is need for scientific way of getting information that is utilized to make effective decisions. Leadership is the means of influencing others to accomplish organization objectives and goals. The leadership skills are influence by traits, beliefs and behaviours under various situations. These were discussed under leadership theories from great man theory to Full range leadership model. Summarily they all show relationship effect of leadership traits, style and behaviours on organizational outcomes. With this theoretical background and various research reviews, research question around some specific issues such as communication, clear leadership direction, adoption of technology and human resources management were formulated. Research stages that will allow us carry out optimal investigative study was itemized one after the other. A suitable and matching data collection method was identified for the leadership questions.

Ethical issues which can arise in the course of the research were highlighted for each research stages and means to minimize their occurrences were suggested.

Lastly, we can conclude that management research is very useful in addressing organizational problems involving any of the management subject area such as leadership.

\section{References Références Referencias}

1. Albert S. K, (1990). Evolution of Leadership Theory.

2. Agwor Thank God \& Osho Adeshina (2017). 'Ethical Issues in conducting research in the behavioural and social sciences', The International Journal of Humanities \& Social Studies. ISSN 2321-92023

3. Anees, U. K (2013). 'Impact of leadership on organizational Performance', a case study of $D$ \& $R$ Cambric communication. Business Economics \& Tourism.

4. Antonakis J, Chester A, Jaccqueline D \& Kishore G (2004). 'Methods for studying leadership'. https: www.researchgate.net/publication/2582221636

5. Apenko, S \& Chernobaeva, G (2016). 'The influence of complex adaptive leadership on the efficiency of business management'. Proceedings of the European Conference on Management, Leadership \& Governance, 17-24. Retrieved from http://www .academic-conferences.org/

6. Avolio B. J, Kahai S. S, Dodge G. E. (2001). 'Eleadership: implications for theory research and practice'. Leadersh. Q11:615 - 68.

7. Ayomikun, I. (2017). 'Effectiveness of Performance appraisal system and its effect on employee motivation'. Nile Journal of Business and Economics. doi:10.20321/niiejbe.v315.88

8. Bass, B. M. (1985). Leadership and Performance beyond expectations: Free Press, New York, N.Y

9. Bass, B. M. (1990a). Bass and Stogdil's handbook on leadership: ( $3^{\text {rd }}$ ed). New York, N. Y: Free Press

10. Bass, B. M \& Riggio R. E. (2006). Transformational Leadership: Lawrence Erlbaum Associates, Mahwah, $\mathrm{NJ}$

11. Blake R. R and Mouton J. S. (1994). The Managerial Grid: Gulf Publication, Houston, US.

12. Calloway, J. A \& Awadzi, W. (2008). 'Leadership and Organizational success: an examination of the traits, skills and transformational approaches'. Consortium Journal of Hospitality \& Tourism 12 (1), 13 - 23.

13. Celestine, A. A. (2015). 'Effects of leadership styles on employee performance at BOA Kenya Ltd'. MSc Thesis submitted to Open University of Tanzania

14. Chiau, W. L, Hsu, P. Y \& Huang, C. M. (2011). 'Perceptions of the impact of Chief Executive Leadership style on organizational performance through successful enterprise resource planning'. Social Behaviour and Personality: An International Journal, 39(7), 865 - 878. Doi:10.2224/sbp.201 1.39.7.865

15. Clark, K \& Clark, M. (1990). 'Measures of Leadership. West Orange, $\mathrm{NJ}$ : Leadership Library of America'. Journal of International Business Research 8(2), 133 - 139

16. Colfax, R. S, Santosa, A. T \& Diego, J. (2009). 'Virtual leadership: A green possibility in critical times but can it really work' 
17. Cooper, D. R \& Schnider, P.S (2007). Business Research Methods. New Delhi: Tata McGraw-Hill Edition

18. David, E. G. (2004). Doing Research in the Real World: SAGE Publisher, London. ISBN 1446296172.

19. David, L. K. (2014). 'Leading from within: Building organizational leadership capacity'. http://www.ie dconline.org-/leading_from_within.pdf

20. Deepak, V. (2015). 'Communication: A necessary leadership skill'. https://researchgate.net>public cation > 282652228_communication_A necessary I eadership_skill/link/5615f7f308aec6224422f154/dow nload

21. Don-Solomon, A, Amakiri, E \& Gift, J. (2018). 'Ontological \& Epistemological Philosophies underlying theory building: A scholarly Dilemma or axiomatic illumination-the business research perspective'. European Journal Of Business and Innovation Research, 6(2), p 1-7

22. Downton, J.V. (1973). Rebel Leadership: commitment and Charisma in the revolutionary process: Free Press, New York, 1973

23. Geoff, L. (2005). Research Methods in Management, a concise introduction to research in management and business consultancy: Elseview Butterworth-Heinemann, MA, USA

24. Garcia, M, Duncan, P, Carmody-Bubb, M and Ree, M.J. (2014). 'Psychology', 5(3), p 204. Scientific Research Publishing Inc.

25. Gill, R. (2006). Theory and Practice of Leadership: SAGE Publications, London.

26. Hudson, L. \&Ozanne, J (1998). 'Alternative ways of seeking knowledge in consumer research', 14 (4), 508-521

27. Ifedapo, A. (2013). 'First Bank of Nigeria: Restructuring to High Performance'. South Asian Journal of Business and Management cases. 2(1), 51 - 60. Doi: 10.1771227797791348065

28. Jeroen, S, Martin, W and Jo, R. (2019). 'Leadership styles in technology acceptance: Do followers practice what leaders preach?'. Journal of Science Theory and Practice. Doi: 10.1108/096045205 10633998

29. Johnson, P. Duberley, J. (2003). Understanding management Research: An introduction to epistemology. London: Sage Publications.

30. Johnson, R. \& Christensen, L. (2010). Educational Research: Quantitative, qualitative and mixed approaches $\left(4^{\text {th }}\right.$ ed) California: Sage Publications.

31. Joseph, T. T. (2008). 'Epistemology theory and methodology in Knowledge Organization: Toward a Classification, methodology and Research Framework In knowledge Organization', 35 (2/3): 102-112. The Information School of the University of Washington.
32. Karnakar, A \& Datta, B. S. (2012). Principles and Practice of Management and Business Communication: India, Dorling Kindersly Ltd.

33. Khurana, R. (20027). From higher aims to hired hands: the social transformation of American Business Schools and the Unfulfilled promise of Management as Profession: Princeton University Press, Princeton and Oxford

34. Kishore, J, Vasundhra, S, Anand, T. (2011). 'Formulation of a research question'. Indian Journal of Medical Spec. 2011; 2, 184 - 8

35. Kozlowski, S. J \& Bell, B.S. (2003). Work groups and teams in organizations. In Handbook of Psychology: Industrial and Organizational Psychology ed, WCborman, DRilgen, RJ, Klimoski, p 333 75, London: Wiley

36. Kurt, V, Geert, L, \& Peter D, (2019). 'Book HighlightSetting a clear strategic direction'. Article in Global Business and Organizational Excellence. doi:10.1002/joe.21952

37. Lonnie, M. (2017). 'The Impact of emerging technology on leadership development'. https:// www.researchgate.net/publication/341464180

38. Manichander, T \& Manjula, H.S. (2016). Management of School Education: Laxmi Book Publication, India.

39. Mazurkiewics, G. (2012). Leadership and mental models. Study of school principals' awareness: Zarzadzanie Publiczne, (20); 27 - 48.

40. Meyer J.P, 2013. The science-practice gap and employee engagement: it's a matter of principle. Canadian Psychology 54 (4), 235 - 245. Doi: 10.1037/90034521

41. Muhammad, E. H. (2016). 'Investigating leadership practices in retail banking in South Africa: a case study of Nedbank'. Banks and Bank Systems, 11(3), 17 - 27. doi:10.21511/bbs.11 (3).2016.02

42. Muhammad, A \& Sadia, A. (2018). 'The many faces of leadership: proposing research agenda through a review of literature'. Future business Journal, 4(2), p $179-188$

43. Munevver, C, Melisa, E K, Mehmet, N. (2012). 'The effects of leadership styles and the communication competency of Bank Managers on the employee's job satisfaction: the case of Turkish banks'

44. Navindhra, N. (2011). 'What is Research? A conceptual understanding'. Department of Emergency Medical Sciences Cape Peninsula University of Technology, Bellville 7535, South Africa

45. Neilsen, K \& Munir, F. (2009). 'How do transformational leaders influence followers' affective well-being. Exploring the mediated role of self-efficacy'. Work stress, 23 (4), 313 - 329. Doi: 10.1080102678370903385106

46. Northouse, P. G. (2007). Leadership: Theory and Practice: SAGE Publications, Thousand Oaks. 
47. Northouse, P. G. (2013). Leadership Theory and Practice $\left(6^{\text {th }}\right.$ ed.): Thousand Oaks, CA: Sage Publications

48. Prabash, E. S. (2012). Interpretivism and Positivism Ontological and Epistemological Perspectives Research Paradigms and Approaches: Newcastle Business School, Northumbra University, UK.

49. Rafique, D. (2014). 'The Role of leadership in the effective management of corporate strategy: A case study at Data Bank Ghana'

50. Rashad, Y \& Haswing, T. T. (2013). 'The review of communication methods used by leaders employing various basic leadership styles'. https:// www.reserachgare.net/publication/256296344

51. Ravazadeh, N \& Ravazadeh, A. (2013). 'The effect of transformational leadership on staff empowerment'. International Journal of Business and Social Science, 4(10).

52. Robinson, M. A \& Boies, K. (2016). 'Different ways to get the job done: comparing the effects of intellectual stimulation and contingent reward leadership on task-related outcomes'. Journal of Applied Social Psychology, 46 (6), 336 - 353. doi:10.111/jasp.12367

53. Ruhi, B \& Nolan, M. (2014). 'Ethical Issues in Research'. https://www.researchgate.net/public ation/45111693

54. Salim, M, Bakhit, A, \& Azmi, M. (2015). 'Methodological considerations in studying transformational leadership and its outcomes'. International Journal of Engineering Business Management. https://doi.org/10.5772/60429

55. Sarachek, B. (1968). 'Greek concepts of leadership'. The Academy of Management Journal, 11(1), 1968, p 39-48

56. Sinmi, K, Ratan, T, John, R. (2019). 'Formulation of research question-stepwise approach'. Journal of Indian Association of Pediatric Surgeon, Jan - Mar, 24(1): 15 - 20. doi:10.4103/jiaps.JIAPS 7618

57. Smith, J. E, Carson, K. P \& Alexander, R.A. (1984). 'Leadership: it can make a difference'. Academy of Management Journal, 27, 765 - 776

58. Sreejesh, S, Mohapatra, S \& Anusree, M. R. (2014.) 'Business Research methods: an applied orientation'. ISBN: 978-3-319-00538-6. http://www .springer.com/978-3-319-00538-6

59. Sudha, K. S, Shahnawaz, M. G \& Farhat, A. (2016). 'Leadership Styles, leader's effectiveness and wellbeing: exploring collective efficacy as mediator'. Vision (09722629), 20 (2), 111-120 doi.10.1 177/0972262916637260

60. Syed, M.S. (2016). Introduction to Research, 2016. Basic guidelines for Research: An Introductory Approaches for All disciplines: (p 1-22). $1^{\text {st }}$ Edition, Book Zone Publication, Chittagong 4203, Bangladesh.
61. Tharenou, P, Donohue, R and Cooper, B. (2007). Management Research Methods: Cambridge University Press. https://doi.org/10:1017/CB09780 511810527

62. Tsui, A. (2016). 'Reflections on the so-called value ideal: a Call for responsible science in business schools'. Cross cultural and strategic management, 23 (1), p $4-28$

63. Umesh, R \& Nitin, B. (2014). 'Management research: To understand the role of epistemology in management research'. Journal of management and science. ISSN2249-1260,4 (1)

64. Wasim, A \& Asghar, I. (2010). 'The role of leadership in organizational change: relating the successful organizational change with visionary and innovative leadership'.oai.D.VA.org: ting-7037. Urn: nbn: se: hg: diva-7037

65. Zaech, S \& Baldegger, U. (2017). 'Leadership in Start-ups'. International Small Business Journal, 35 (2), 157 - 177. Doi: 10.1177/0266242616676883

66. Zulch, B. (2014). 'Leadership Communication in Project Management' proceedings 27 $7^{\text {th }}$ IPMA World Congress on Social and Behavioural Science 2014, University of the Free state, Bloemfontem South Africa 